\title{
Effect of Processing on Nutrients and Rumen Microbial Characteristics of WAD Sheep Fed Gmelina arborea Leaf Based Diets
}

\author{
Dr. Okpara Oghenesuvwe ${ }^{1, *}$, Professor Greg Okagbare ${ }^{2}$, Dr. Akaninyene \\ Asuquo Jack ${ }^{3}$
}

\author{
${ }^{1}$ Department of Animal Science, Delta State University, Asaba Campus, Delta State, Nigeria. \\ ${ }^{2}$ National Open University, Abuja \\ ${ }^{3}$ Department of Animal Science University of Ibadan, Oyo State, Nigeria
}

\begin{abstract}
Low pasture quality and quantity adversely affect the performance of ruminants in the tropics. This necessitated the search for other feed resources that could augment the deficit, particularly, in the dry season. However, some of these feed resources contain phytochemicals which if not properly processed could be detrimental to ruminants. This study was carried out to determine the effects of processing on nutrients, phytochemicals and microbial characteristics of WAD sheep fed processed Gmelina arborea leaf based diets. Gmelina arborea leaves (GAL) were harvested and used as fresh, chopped, sun-dried, air-dried and boiled-dried. Nutrients and phytochemicals were determined from samples. Rations were comprised in the following proportions; 11 (50\% Penniseum purpureurn: $50 \%$ fresh Gmelina arborea leaves), T2 (40\% Penniseum purpureurn: 60\% chopped Gmelina arborea leaves), T3 (40\% Penniseum purpureurn: 60\% air dried Gmelina arborea leaves), T4 (40\% Penniseum purpureurn : 60\% sun dried Gmelina arborea leaves), T5 (40\% Penniseum purpureurn : 60\% boil dried Gmelina arborea leaves). Forty WAD sheep (6-8 months) were randomly assigned to one of the rations with eight sheep per group in a completely randomized design. Ninety days post-feeding, rumen liquor was collected for microbial assay using standard procedure. The CP and calcium were increased in T1 and T2 compared to others except for NFE which was reduced. Tannin and saponin increased in T1 and T2 but reduced in T5. Streptococcus spp was absent in T5 compared to T1 and T2. Lower total bacteria count was observed in $T 5$ compared to other treatments. Boiled-drying reduced the crude protein and phytochemicals contents of Gmelina arborea leaves with reduction in total bacteria count in the rumen.
\end{abstract}

Keywords-Detoxification, Gmelina arborea leaves, Phytochemicals, Streptococcus spp, Total bacteria count, West African dwarf sheep.

\section{INTRODUCTION}

The introduction of novel feedstuffs to ruminant due to the limitation in quantity and quality of available pasture especially during the dry season has raised yet another challenge. Although some of these feed resources beyond their nutrient content are medicinal, they contain phytochemicals that could be detrimental to animals if not properly harnessed. Adequate processing of these feedstuffs could therefore complement native pasture supply which ruminants in the tropics are mostly dependent on.

Gmelina arborea is a fast growing evergreen browse tree that yields considerable quantity of fodder at the topmost dry period. Its leaves show some promise as feeding stuff for ruminant based on its high nutritive value of $22.29 \%$ crude protein and $6.28 \%$ ash content (Okagbare et al., 2004). This enormous potential in Gmelina arborea could have positive impact on ruminant productivity. However, the presence of variable amounts of reduced tannin with other phytochemical in their biomass influences their optimal use by animals (Osakwe 2003). Gmelina arborea have also been reported to have poor nutrient utilization when fed solely or at higher levels (Okagbare et al., 2003, Akpodiete and Osayuwu, 2005). Therefore, to achieve maximum nutritional potential of this feedstuff processing becomes imperative to detoxify the unwanted endogenous compounds that have the ability to lower nutritive value and could result in mortality in ruminants. Some of these 
unwanted endogenous compounds are heat-labile (D’Mello, 2000), hence, heat treatments such as boiling and toasting can be used to reduce the effect of the antinutritional factors present in browse plants (Ahamefule, 2002). Moisture content could also be modified for processing purposes so as to have safer storage, increase palatability and nutrient availability and this may be done by physical, chemical, thermal, bacterial methods or other alterations of feedstuff before it is fed to ruminants (Campling, 1970; Church, 1971).

Rumen microbes play important role in the overall productivity of ruminant animals. They act as intermediary between feed and the host animal. The rumen contains a variety of these microbes and they exist in a symbiotic relationship with the host animal. The basic microbes are bacteria, fungi, and protozoa and they are of different types, population and specific substrate dependent. The bacteria composition of the rumen as reported by Karma (2005) was $10^{10-} 10^{11}$ cells $/ \mathrm{mL}$ which represents more than 50 genera of the entire bacteria population, ciliate protozoa $\left(10^{4}-10^{6} / \mathrm{mL}\right.$, from 25 genera), anaerobic fungi $\left(10^{3}-10^{5}\right.$ zoospores $/ \mathrm{mL}$, representing five genera) and bacteriophages $\left(10^{8}-10^{9} / \mathrm{mL}\right)$. Phytochemicals including tannin, saponin, flavonoids, and alkaloids have antimicrobial properties and when in feed can selectively inhibits more of the gram positives bacteria than the gram negatives. Faniyi (2016) reported that herbs suppressed gram positive bacteria and enhanced the population of gram negatives in sheep in vitro. Broudiscou et al. (2002) also in their study revealed that some plant species stimulated microorganisms while concomitantly decreasing methane production. Saponin inhibits protozoa and also reduces hydrogen availability for methanogenesis (Guo et al., 2008). The gram positive bacteria are the ammonia, hydrogen, formate, lactate and butyrate producers while the gram negatives are the propionic acid and succinate producers (Nagaraja et al., 1997). The efficiency of the rumen would therefore be dependent on the type of microbes dominating the rumen at a particular time. This however, would be influenced by the effect of phytochemicals on the different microbial population.

This novel study was to determine the consequence of processing on nutrients composition, phytochemicals and the microbial characteristics of West African Dwarf (WAD) sheep fed differently processed Gmelina arborea leaf based diets.

\section{MATERIALS AND METHODS}

\subsection{Experimental Location}

The experiment was carried out at the Ruminant Unit of the Teaching and Research Farm and the Laboratories of the Department of Animal Science, Delta State University, Asaba campus.

\subsection{Sample Assortment and Processing of Gmelina arborea Leaves}

Two hundred and fifty grammes of fresh Gmelina arborea leaves harvested from the premise of Delta State University, Asaba Campus was used for this study. The harvested Gmelina arborea leaves were weighed and processed as fresh, chopped, air-dried, sun dried and boiled dried samples.

Fresh: The fresh leaf samples collected were crushed in a mortar and packed in a cellophane bag.

Chopped: The leaf samples collected were chopped and crushed in a mortar, after which they were packed in a cellophane bag

Air dried: The leaves were spread on a drying platform and kept in a well-ventilated room at a mean temperature of $28.5^{\circ} \mathrm{c}$ for two days. The leaves were turned occasionally to ensure even drying

Sun dried: The leaves were placed on a special drying platform and placed under direct sunlight on a roof away from animals and dust at a mean temperature of $33.2^{\circ} \mathrm{c}$ for two days.

Boiled dried: The leaves sample were boiled for about 3 minutes and thereafter sun dried for 48 hours.

\subsection{Experimental Animals, Housing, and Feeding Management}

Forty WAD sheep with weight range of $7-9 \mathrm{~kg}$ and age ranged of $6-8$ months procured from a reputable farm in Asaba were used for this study. In a completely randomized design the animals were allocated into five treatments of eight (8) animals each on the basis of average body weight. The ration offered to each treatment consists of processed Gmelina arborea leaves (GAL) and elephant grass (Penniseum purpureurn) in the following proportions: T1 (50\% Penniseum purpureurn: 50\% fresh Gmelina arborea leaves), T2 (40\% Penniseum purpureurn: 60\% chopped Gmelina arborea leaves), T3 (40\% Penniseum purpureurn: $60 \%$ air dried Gmelina arborea leaves), T4 (40\% Penniseum purpureurn : 60\% sun dried Gmelina arborea leaves), T5 (40\% Penniseum purpureurn : 60\% boil-dried Gmelina arborea leaves). The animals had ad libitum access to feed and water. The animals were subjected to 14 
days adaptation period before the beginning of the 90 days feeding trial.

The Sheep were treated against ectoparasites and endoparasites using ivomec injection, diazintol solution and also administered long acting antibiotics injection. Proper vaccination of the animals was also carried out.

\subsection{Rumen Microbial Assay of West African Dwarf Sheep Fed Diets with Processed Gmelina arborea Leaves}

At the end of the trial, sample of rumen liquor was collected in a sterile bottle from the animals slaughtered in each treatment and kept. Serial dilution was done and inoculation carried out using pour plate method. The sample was incubated and sub-cultured to get pure strains. Isolation and identification of parasite present in the rumen sample was done by wet analysis as described by/ according to (Menke and Steingass 1988).Rumen bacteria isolation was carried out as described by Levett (1990). The method described by Ogimoto and Imai (1981) was used for the identification of rumen microbes.

\subsection{Chemical Analyses}

The processed feed samples of GAL were ground in a hammer mill to pass a $2 \mathrm{~mm}$ mesh sieve before proximate analysis were carried out according to AOAC (2000). The fibre fractions which consists of acid detergent fibre (ADF) and neutral detergent fibre (ADF) were analyzed using the procedures of Van Soest et al. (1991). Mineral contents were analyzed from the ashed samples. Calcium, was determined by flame emission spectrophotometry method using Jenway digital flame photometer (Wiseman and Cole, 1990). The tannin content was estimated using the technique described by Makkar (1993). Total saponin content was determined using a spectrophotometric method according to Hiai et al. (1976). Alkaloid, flavonoids and oxalate were determined using the technique of Bohm and Kocipai-Abyazahi (1994). The method described by Smith et al. (1995) was used to determine the steroid content of GAL.

\subsection{Statistical Analysis}

Data obtained were subjected to Analysis of Variance following the procedure of Steel and Torrie (1980) and difference between means separated using the Duncan Multiple Range Tests according to Duncan (1955) using the procedures of SAS (2000).

\section{RESULTS}

The CP, CF, EE, Ash, NDF, ADF and calcium were consistently higher in fresh GAL and chopped GAL compared to sun dried, air dried and boiled dried except for
NFE which was lower (Table1). Tannin, saponin, alkaloid, oxalate, flavonoid and steroid were consistently higher in fresh and chopped GAL but lower in boiled dried (Table 2). Scanty growth of suspected Staphylococcus spp were observed in boiled dried GAL compared to fresh and chopped GAL, with the absence of Streptococcus spp and Escherichia spp (Table 3). A few ova of round worm and cyst of Escherichia spp in their pus cell were observed in boiled dried compared to fresh and chopped (Table 4). Lower total bacteria count was observed in boiled dried compared to other treatments (Table 5).

\section{DISCUSSION}

The lower CP in the boiled-dried Gmelina arborea leaves may be ascribed to the effect of heat treatment which possibly may have denatured some protein components. Ahamefule and Udo (2010) reported that heating as a processing method lowers the crude protein content of pigeon pea compare to the raw seed. However, the $\mathrm{CP}$ content of the processed Gmelina arborea leaves obtained in this study was still more than the proposed $7 \%$ value for tropical livestock by Minson (1990), below which their performance will be negatively affected. This may be deliberated as a significant factor in the use of processed GAL in ruminants' diet because feed intake by ruminants is correlated to the crude protein content of diets (Alderman, 1980). The crude protein values obtained in this study is similar with prior reported values by earlier workers (Okagbare et al., 2014; Adamu et al., 2013) but higher than those reported by Osuntokun and Olajubu (2014). The lower ether extract could be attributed to heat treatments which favored fat volatilization compared to the fresh and chopped treatments. The ash contents of Gmelina arborea leaves of fresh and chopped treatments were higher than those reported by Adamu et al. (2013). Ether extract, neutral detergent fibre, acid detergent fibre and nitrogen free extract values of Gmelina arborea leaves obtained in the present study are similar to the reports of Onabanjo and Onwuka (1998), Okagbare et al. (2014) and Babayemi et al. (2005). These values are also in consonant with the recommended nutritional requirements for ruminants reported by Idahor, (2006). However, the high level of nutrients composition of Gmelina arborea leaves proposes that they are possible viable feed resources that could be utilized in ruminant feeding for optimal performance (Okpara, 2020). These findings offer an incentive for the implementation of these processing methods for enhancement in ruminant feeding.

The presence of alkaloid, tannin, steroid, flavonoid, oxalate and saponin depicts the possible toxicity of the feed resources if not properly processed. The decline in the 
concentration of the potential toxicants concentrations could be attributed to the heat labile nature of the antinutritional factors as affected by the different processing methods. This finding is in agreement with the reports of D'mello (2000), Ikhimioya (2005), Idahor (2006) and Ahamefule and Udo (2010). Boiling, toasting and soaking could be useful processing methods for the conversion of the anti-nutritive effect of some phytochemicals to useful products (Ahamefule, 2002). Osuntokun and Olajuba (2014) reported that boiling, simmering and blanching significant reduced the level of cyanide content in Moringa oleifera leaves. Mada et al. (2012) reported reduced oxalate content in Arachis hypogea due to boiling. The use of browse tree products such as neem leaf meal as animal feed resource is limited by the presence of bioactive compounds which limit its nutrient utilization (Ogbuewu, 2009). However, these bioactive compounds were reduced by sun drying, which is another form of heat treatment (Obikaonu et al., 2012). The concentration of saponin, flavonoid, alkaloid, oxalate in GAL obtained in this study are comparable to reports of Idahor (2006), and are within the acceptable levels for ruminant nutrition (Idahor, 2006). However, Osuntokun and Olajuba (2014) reported lower concentration of saponin, flavonoid and alkaloid in some selected species of browse plants. Tannin obtained in this study was comparable to those of some selected tropical plants reported by Osuntokun and Olajuba (2014).Tannin directly inhibits methanogens and indirectly reduces methane production by reducing available hydrogen, binding with proteins and inactivating rumen microbial enzymes (Tavendale et al., 2005, Jouany and Morgavi, 2007, Barry and McNabb, 1999). Saponin inhibits protozoa and also reduce hydrogen availability for methanogenesis (Guo et al., 2008) by forming complex with sterols in protozoal cell membranes resulting in activity inhibition and cell lysis (Cheeke, 2000). Cowan (1999) reported that the antimicrobial activities of flavonoids could be due to their capability to form complexes with extracellular and soluble proteins, as well as bacteria cell walls. Flavonoid directly inhibits methanogens (Bodas et al., 2012). Alkaloids possess microbiocidal effects (Ghoshal et al., 1996). Yikal (2015) reported that oxalic acid binds with calcium to form calcium oxalate which unfavorably affects the utilization and absorption of calcium in the animal body. These phytochemicals could be beneficial when tree foliage are properly processed and used within limits but detrimental when in excess thus their potential toxicity. For instance, tannin is beneficial at $2-4 \%$ concentration of the diet's dry matter where it binds dietary protein and protects it from microbial attacks in the rumen (Barry, 1983) and increase absorption of essential amino acids (Barry, 1989).
Other positive effects of tannin in animal feeding as reported by Adesogan (1983) include bloat prevention, increased efficiency of protein utilization, reduction of parasite burden, reduction of proteolysis during ensilage, increased quality of animal products and defaunation of the rumen. Its anti-nutritional effect sets in when beyond $4 \%$ with the depression of feed intake in ruminants, reduction of nitrogen retention and reduced ruminal fibre digestibility (Idahor 2006). At 5-9\%, it inhibits the activity of bacteria and anaerobic fungi and reduces feed intake (Akin and Rigsby, 1985, Leng 1997). Above 9\% tannins may become lethal to an animal dependent on no other feed (Kumar, 1983). However, a little tannin above the tolerant level has been usually accepted to protect protein of forages and allow a higher efficiency of feed utilization by the animal (Idahor 2006). Processing of Gmelina arborea could therefore go a long way in the determination of the nutritive or anti-nutritive role it could play in ruminant nutrition.

The boiled dried GAL diet (T5) recorded scanty growth of suspected Staphylococcus spp and few ova of round worm when compared to fresh (T1) and chopped (T2) diet. T5 also recorded few cyst of Escherichia spp in their pus-cell and had lower total bacteria count compared to T1 and T2. These could be attributed to the reduction in the concentration, detoxification/debitterization of the possible toxicity of the phytochemicals in the boiled-dried diet (T5) offered to the animals, which favored increased intake and consequently increased antimicrobial activity of the phytochemicals. On the other hand, diets with high concentration, without the detoxification/debitterization of phytochemicals may likely be less palatable and intake would be negatively affected thereby reducing the potential impact of phytochemicals on rumen microbes as indicated in the fresh and chopped diet. Creevy et al. (2014) was of the view that microbial yield is an important index to measure the amount of microbial protein made available to the animal each day. This may imply that low count equates low microbial protein. However, this may not hold for all microbial entity particularly when the phytochemicals present are high as with the fresh and chopped GAL diet in this study.

The role of microbes in the rumen is central to ruminant productivity. It plays an intermediary role between the feed consumed and the effect on the host animal. The population and type of microbes (bacteria) present significantly affect the type of ruminal output. As reported in the study, the isolate distribution and total count of microbial species (Table 5) revealed that sheep fed fresh diet of GAL recorded the highest total bacteria count of (94), followed by sheep fed chopped (93). However there 
was a decline on the total bacteria on sheep fed air dried (65), sun dried (48) and boiled dried (21). This is in agreement with Creevy et al. (2014).

Kemp and Lander (1984) grouped bacteria isolates into group A and group B bacteria. The group A bacteria were later reported by Harfoot and Hazzlewood (1997) to be mainly gram positive bacteria while the group B were mainly gram negative bacteria. The gram positive bacteria reported in this study were of Staphylococus spp, Streptococcus spp while Escherichia spp was the only specie of gram negative bacteria recorded. The gram positive bacteria have been reported to be responsible for the conversion of unsaturated fatty acids to mainly vaccenic acid while the gram negatives converts vaccenic to mainly stearic acid (Kemp and Lander, 1984; Harfoot and Hazzlewood, 1997). Although both gram positive and gram negative bacteria are involved in the biohydrogenation of unsaturated fatty acids, the reduction in the population of gram positive bacteria would likely reduce the rate of conversion of unsaturated fatty acids and the complementary effect of the gram negatives in the complete saturation of unsaturated fatty acids.

Hook et al.(2010) reported that gram positive bacteria are contribute significantly to the production of methane in the rumen due to the fact that they provide methane producing bacteria the substrates needed for methane production. This cross-feeding of methanogens is as a result of the hydrogen producing activity of the gram positives. Russell et al. (1988) reported that gram positive bacteria produce more ammonia in the rumen compared to the gram negatives since they utilize amino acids and peptides as energy source instead of carbohydrates. Peptides and amino acids are products of protein degradation which are fermented in the rumen to form ammonia nitrogen (Hungate, 1966). Bacteria play different roles in the different steps in the biohydrogenation of saturated fatty acids in the rumen (Nam and Garnsworthy, 2007).

Alteration of protein solubility which increased bypass protein value, reduction of phytochemical content and the formation of mild browning reaction between the protein and sugar content of leaf meal are due to drying (Ahn, 1990; Norton, 1994; Leng, 1997). Heat treatments to tree foliage seem to increase protection on protein with optimal drying temperature of $130^{\circ} \mathrm{C}$. Ahn (1990) reported zero extractable tannin concentration in Gliricidia leaves after drying. Additionally, Dalzell (1996) reported 25\% reduction in extractable tannins from freeze dried samples after drying. Goering and Waldo (1974) reported an optimal drying temperature of $130^{\circ} \mathrm{C}$ for reduced nitrogen solubility, increased nitrogen digestibility and increased nitrogen retention in lambs. Sheep supplemented with dried Gliricidia leaves had better intake of straw, nitrogen digestibility and nitrogen retention (Ahn, 1990). Goats offered dried foliages had better growth performance compared to those on the same quantity of fresh one with both on same poor quality basal diet (Robertson 1988; Norton, 1994). The different processing methods used in this study exerted varying heat effects and this could have played significant roles in reducing the concentration of phytochemicals hence the shift from anti-nutritional factors to agents that could manipulate the rumen for improve productivity.

Phytochemicals such as tannins and saponins have antibacterial properties (Charis 2000; Tipu et al., 2006) particularly on gram positive bacteria due to their simpler cell membrane (Wina et al., 2006).The inhibition of gram positive hydrogen generating bacteria in the rumen can lower the quantity of hydrogen available for biohydrogenation of unsaturated fatty acids and also for the production of methane (Miri et al., 2013). The inhibition of gram positive bacteria in the rumen and the movement of the biomass from the rumen towards the intestines may also increase the product of biohydrogenation associated with them which would probably be more of the unsaturates and intermediates (Jack, 2018). The passage of increased concentration of unsaturated fatty acids and intermediate products of biohydrogenation to the host animal could therefore be a signal to the potential benefits that could be derived from the consumption of ruminant products beyond its nutriments.

\section{CONCLUSION}

Treatment with boiled-dried Gmelina arborea leaves reduced protein, tannin, saponin, flavonoid, alkaloid, oxalate and steroid compared to the fresh and chopped treatments. Endoparasites and total bacteria count were also lowered by boiled-dried treatment. While the protein level was still within levels that could positively impact on growth of the animal, the reduced phytochemicals allowed for increased intake for better pharmacological effect on the microbial population and in effect, host animal. Therefore, Gmelina arborea leaves offered to ruminant should be boiled-dried for enhanced utilization and ruminant productivity.

Human and Animal Rights: This study was approved and carried out to conform with regulatory standards of the Institutional Ethics Committee of the Department of Animal Science, Delta State University, Asaba campus. The handling, care and treatment of animals used for this study were in compliance with provisions contained in the Research Policy Handbook of Delta State University, 
Asaba campus and aimed at reducing discomfort and pain to the animals.

\section{CONFLICT OF INTEREST}

There was no conflict of interest and the source of funding was from personal income and savings of Dr. Okpara Oghenesuvwe.

\section{ACKNOWLEDGEMENTS}

The work was designed and carried out by Dr Okpara Oghenesuvwe. Dr Akaninyene Asuquo Jack wrote the manuscript in consultation with Dr Okpara Oghenesuvwe. The final draft was agreed on by both authors.

\section{REFERENCES}

[1] Adamu HY, Lamidi OS, Ehoche OW, Abdu SB, Hassan MR, Yashim SM. Growth performance of Yankasa rams fed varying proportions of Gmelinaaborea leaves. Nig J AnimSci2013; 15:145-154.

[2] Adesogan EK. Anti-infective agents of plant origin.VISOMP conference.Proc. of 5th International Symposium on Medical Plants Pub.DRPU, UNIFE, Ile-Ife.Essien EE, Adebanjo AO, Adewunmi CO, Odebiyi OO. Eds. 1983.

[3] Ahamefule KU. Evaluation of pigeon pea seeds C. cajan as protein source for pullets. Ph.D. Thesis, Department of Animal Science, University of Nigeria, Nsukka, 2002.

[4] Ahamefule FO, Udo MO. Intake and digestibility of West African Dwarf Goats fed raw or processed pigeon pea (cajanus cajan) seed meal based diets. Animal Science Association of Nigeria conference.Proc. of the $15^{\text {th }}$ conference. University of Uyo, Nigeria,Pp $626-629,2010$.

[5] Ahn JH. Quality assessment of tropical browse legumes: tannin content and nitrogen degradability. PhD Thesis, University of Queensland. 1990.

[6] Akin DE, Rigsby LL. Influence of phenolic acids on rumen fungi. Agron J 1985; 77: 180-182.

[7] Alderman G. Application of Practical Rationing Systems. Proceedings of a workshop in Ottawa, Canada, 12-14 March, 1979, IDRC, Ottawa Canada. In: Standardization of analytical methodology for feeds. Ppigden, In. J. Balch C.C. and Graham, M. (Eds), 1980.Pp. 29-35.

[8] AOAC. Association of Official Analytical Chemists.Official Methods of Analysis (17 thedn.).Washington, D.C. Abstracts Review 2000; 44: 803 - 815.

[9] Babayemi OJ, Bamikole MA, Odedire OA, Otukoya FK and Ogunbosoye DO. Chemical composition and qualitatively determined secondary metabolites of sixteen (16) tropical browse trees in South West Nigeria. Animal Science Association of Nigeria conference. Proc. of $10^{\text {th }}$ Annual Conference. University of Ado- Ekiti Nigeria, 2005. Sept. 12-15, 2005.

[10] Barry TN, McNabb WC. The implication of condensed tannins on the nutritive value of temperate forage fed to ruminants. Bri J Nutr1999; 81:263-272.
[11] Barry TM. The role of condensed tannins in the nutritional value of Lotus pendunculatus for sheep. 3. Rates of body and wool growth. Bri J Nutr 1983; 54, 211-217.

[12] Bary TN. Condensed tannins: their role in ruminant protein and carbohydrate digestion and possible effects upon the rumen ecosystem. In: Nolan JV, Leng RA, Demeyer, DI.Eds. The roles of protozoa and fungi in ruminants digestion. PenambulBooks, Anuidale, NSW, Australia, 1989; 153-169.

[13] Bodas R, Prieto N, Garcia-Gonzalez R, Andres S, Giraldez FJ, Lopez S. Manipulation of rumen fermentation and methane production with plant secondary metabolites. Anim Feed Sci Tech2012; 176(1-4):78-93.

[14] Bohm BA, Kocipai- Abyazan R. Flavonoid and condensed tannins from the leaves of Vaccinum raticulation and Vaccinum calcyimium. Pacific Sci., 1994. 48: 458-463

[15] Broudiscou LP, Papon Y, Broudiscou AF. Effects of dry plant extracts on feed degradation and the production of rumen microbial mass in a dual flow fermenter. Anim Feed SciTech2002; 101: 183-189.

[16] Campling RC. Physiology of digestion and metabolism in the ruminant. In: Phillipson AT, Ed. Oriel Press, Newcastle. Pp1970; 226-234

[17] Charis K. A novel look at a classical approach of plant extracts. Feed Mix (special issue on Neutraceuticals).2000; $19-21$.

[18] Cheeke PR. Actual and potential applications of Yucca schidigera and Quillaja saponaria saponins in human and animal nutrition.JAnimSci2000; 77: 1-10.

[19] Church DC. Digestive physiology and nutrition of ruminants, Vol. 2, Corvallis Oregon, 197; pp. $737-762$.

[20] Cowan MM. Plant products as antimicrobial agents. Review.ClinMicrobiol1999; 12 (4): 564-582.

[21] Creevey CJ, Kelly WJ, Henderson G, Leahy SC. Determining the culturability of the rumen bacterial microbiome.MicrobBiotechnol2014; 7: 467 - 479.

[22] D'Mello JPF. Antinutritional factors and mycotoxins. In: D'Mello JDF, Ed.Farm animal metabolism and nutrition.CAB International, Wallinford, UK, 2000; pp 383403.

[23] Dalzell S. Sampling of condensed tannin analysis of Leucaena foliage. Leucnet News 1996; 2: 5.

[24] Duncan DB.Multiple range and Multiple F. Tests.Biometrics.II, 1955; pp1-243.

[25] Faniyi TO. Effects of some herbs and spices on rumen modulation in West African Dwarf sheep. Ph.D. Thesis, Department of Animal Science, University of Ibadan, Nigeria, 2016; pp 232

[26] Ghoshal S, Krishna Prasad BN, Lakshmi V. Antiamoebic activity of Piper longum fruits against Entamoeba histolyticain vitro and in vivo. J Ethnopharmacol1996; 50:167-170.

[27] Goering HK, Waldo DR. Processing effects on protein utilization by ruminants. In: Proceedings of the 1974 Cornell Nutrition Conference for Feed Manufacturers. Ithaca, New York, Cornell University Press, 1974. 
[28] Guo YQ, Liu JX, Lu Y, Zhu WY, Denman SE,McSweeney CS. Effect of tea saponin on methanogenesis, microbial community structure and expression of morA gene, in cultures of rumen micro-organisms LettApplMicrobiol2008; 47.5:421-426.

[29] Harfoot C,Hazlewood G. Lipid metabolism in the rumen. The rumen microbial ecosystem.Hobson PN, Stewart CS, Eds. Chapman and Hall, London, 1997; 382-426.

[30] Hiai S,Oura H, Nakajima T. Colour reaction of some sapogenins and saponins with Vanillin and Sulfuric acid. J Plant Medicina1976; 29:116-22.

[31] Hook SE, Wright AG,McBride BW. Methanogens: Methane producers of the rumen and the mitigation strategies. Review Article. Archaea2010; Volume 2010, Article ID 945785, 11, http://dx.doi.org/10.1155/2010/945785

[32] Hungate RE. The rumen and its microbes.Academic Press, New York, NY, 1966.

[33] Idahor KO. Evaluation of nutritional potentials of differently processed foliages of Elaeis guinenses, Tithonia diversifolia, Spondias mombin, Termiliana catappa for ruminant nutrition. PhD Thesis, University of Ibadan, Ibadan, Nigeria, 2006.

[34] Ikhimioya I. Chemical composition of some dry season shrub and tree foliages in Edo State of Nigeria, Trop $\mathbf{J}$ AnimSci2005; 23: 62-163.

[35] Jack, 2018.Rumen fermentation, growth performance and meat quality of West African dwarf rams fed diets with water-washed neem (Azadirachta indica A. JUSS) fruit inclusion. PhD Thesis, Department of Animal science, Faculty of Agriculture and Forestry, University of Ibadan, Nigeria, 2018; pp 176

[36] Jouany JP, Morgavi DP. Use of natural products as alternatives to antibiotic feed additives in ruminant production. Anim2007; 1(10):1443-14466.

[37] Kamra DN. Rumen Microbial Ecosystem. Curr Sci 2005; 89(1), 126

[38] Kemp P, Lander DJ. Hydrogenation in vitro of alinolenic acid to stearic acid by mixed culture of pure strains of rumen bacteria. J Gen Microbiol1984; 130: 527-533.

[39] Kumar RA. Chemical and biochemical nature of fodder tree leaf tannin. J Agric Food Chem 1983; 31: 1364-1366.

[40] Leng RA. Tree foliage in ruminant nutrition. Food and Agriculture Organization, Animal production and health paper 139. FAO publication, Rome, 1997.Accessed on 14/06/2019.www. fao.org/3/w7448e/W7448E05.htm

[41] Levett PN. Anaerobic bacteria: a functional biology. Open University Press, Philadelphia, 1990; pp 122.

[42] Mada SB, Garba A, Mohammed A, Mohammad A, Olagunju, A,Mohammed HA. Effects of boiling and roasting on antinutrients and proximate composition of local and some selected improved varieties of Arachis hypogeal L (groundnut). Int J Food Nutr and Safety, 2012; 1(1): 45-53.

[43] Makkar HPS. Anti-nutritional factor in foods for livestock in animal production in Developing Countries, (Occasional Publication No. 16), Bri Soc Anim Prod 1993; UK, pp. 6985.
[44] Menke K. H and Steingass, H. Estimation of the energetic feed value obtained by chemical analysis and in vitro gas production using rumen fluid. Animal Resources Development 1988. 28:7-55.

[45] Minson DJ. Forage in Ruminant nutrition. Academic Press, New York; 1990.

[46] Miri VH, Tyagi AK,EbrahimiSH,Mohini M. Effect of cumin (Cuminumcyminum) seed extract on milk fatty acid profile and methane emission in lactating goats. Small Rum Res2013; 113:66-72.

[47] Nagaraja TG, Newbold CJ, Van Nevel CJ,Demeyer CI. In: Hobson PJ, Stewart CS. Eds.Manipulation of rumen fermentation. The rumen microbial ecosystem.2nd edition. Blackie Academic Professional, London, 1997;523-632.

[48] Nam IS,Garnsworthy PC. Biohydrogenation pathways for linoleic and linolenic acids by Orpinomyces rumen fungus.Asian-Australas J AnimSci2007; 20(11):1694-1698.

[49] Norton BW. In: GutteridgeRC, Shelton HM,Eds.Tree legumes as dietary supplements for ruminants. Forgage Tree Legumes in Tropical Agriculture, CAB International, Wallingford, Oxford,1994; pp. 192-201.

[50] Obikaonu HO, Opara MN, Okoli IC, Okoro VM, Ogbuewu IP, Etuk EB, Udedibie ABI. Haematology and serum biochemical indices of starter broilers fed leaf meal of neem (Azadirachta indica). Journ of Agric Techn 2012; 8(1):7179

[51] Ogbuewu, I.P. Physiological responses of rabbits fed graded levels of neem (Azadirachta indica) leaf meal. M.Sc. Thesis, Federal University of Technology, Owerri. 2009

[52] Ogimoto K, Imai S. Atlas of rumen microbiology. Japan Science Society Press, Tokyo, 1981; pp 158.

[53] Okabgare GO, Akpodiete OJ,Esiekpe O,Onagbesan OM. Evaluation of Gmelinaarborea leaves supplemented with grass (Panicum maximum and Pennisetumpurpureum) as feed for West African Dwarf Goats. Trop. Anim. Health and Prod2004; 36:593-598.

[54] Okagbare GO, Okpara O, AkporarhoPO.Determination of browse intake amd nutrient digestability of grazing west Africa dwarf goats fed verying level ofGmilinaarborea leaves as supplements. Int JAnim Vet Adv 2014; 6(2): 5257.

[55] Okpara O., 2020 Feed intake, growth and nutrient utilization of West African dwarf sheep fed differently processed Gmelina arborea Roxb. leaves based diets: performance of WAD sheep on differently processed Gmelina arborea leaves. ABAH Bioflux 12(1):18

[56] Onabanjo OO,Onwuka CFI.Nigeria Society of Animal Production.Proc. of Conference.Gmelinaarborealeaves and some supplements as dry season feed for West African Dwarf (Fouta djallon) Goats. Abeokuta,1998;369-370.

[57] Osakwe LL. Nigerian Society for Animal Production.Proc. of the $28^{\text {th }}$ Annual Conference.Effect of dried Morindalucida supplementation on nitrogen and energy retention of sheep fed basal hay diet. Institute of Agricultural Research and 
Training, ObafemiAwolowo University, Ibadan, 2003; Vol $28,263-5$

[58] Osuntokun OT,Olajubu FA. Comparative study of phytochemical and proximate analysis of seven Nigerian medicinal plant. ApplSci Res J 2014; 2(1)10-26.

[59] Robertson BM. The nutritive value of five browse legumes fed as supplements to goats offered a basal rice straw diet. MAgSc Thesis, University of Queensland, 1988.

[60] Russell JB, Strobel HJ, Chen G. Enrichment and isolation of a ruminal bacterium with a very high specific activity of ammonia production. Appl Environ Microbiol 1988; 54: 872-877.

[61] Smith JW, Larbi A, Jabbar MA, Akinlade J. Voluntary intake by sheep and goats of Gliricidiasepium fed in three states and at three levels of supplementation to a basal diet of Panicum maximum. Agro-For-Syst1995; 32: 287-295.

[62] Statistical Analysis Systems. SAS/STAT Guide for personal computers. Version 6, S.A.S Inst. Inc. Cary New York.USA, 2000.

[63] Steel RGD, Torrie JH. Principles and procedures of statistics.A biometrical approach, $2^{\text {nd }}$ Edn.McGraw-Hill Book Co., Inc., New York; 1980.

[64] Tavendale MH, Meagher LP, Pacheco D, Walker N, Attwood GT,Sivakumaran S. Methane production from in vitro rumen incubations with Lotus pedunculatus and Medicago sativa, and effects of extractable condensed tannin fractions on methanogenesis. Anim Feed Sci Tech2005;123124: 403-419.

[65] Tipu MA, Akhtar MS, Anjumi MI,Raja ML.New dimension of medicinal plants as animal feed.Pak Vet J2006; 26 (3): 144-48.

[66] Van Soest PJ, Robertson JB,Lewis BA. Method of dietary fiber, neutral detergent fiber and non-starch polysaccharides in relation to animal nutrition.J Dairy Sci1991; 74:35833597.

[67] Williams AG, Coleman AG. The Rumen Protozoa. SpringerVerlag, New York, NY, 1992.

[68] Wina E, Muetzel S, Becker K. The dynamics of major fibrolytic microbes and enzyme activity in the rumen in response to short- and long-term feeding of Sapindusrarksaponins.J of ApplMicrobiol2006;100:114122.

[69] Wiseman J, Cole DJA. Variability in the nutritive value of fats for non ruminants in feedstuff evaluation. Butterworth, London. 1990. p. 215

[70] Yilkal T. Important anti-nutritional substances and inherent toxicants of feeds. Food Sci Quality Manage 2015. Vol. 36.

Table.1: Chemical composition differently processed Gmelina arborea leaves ( $\mathrm{g} / 100 \mathrm{gDM})$

\begin{tabular}{lllllll}
\hline Items (\%) & \multicolumn{3}{c}{ Processing Techniques } & SEM \\
\cline { 2 - 5 } & Fresh & Chopped & Sun-dried & Air-dried & Boiled-dried & \\
\hline Crude Protein & $20.95^{\mathrm{a}}$ & $20.75^{\mathrm{a}}$ & $19.08^{\mathrm{b}}$ & $19.79^{\mathrm{b}}$ & $18.05^{\mathrm{c}}$ & 0.33 \\
Crude Fibre & $14.18^{\mathrm{a}}$ & $14.17^{\mathrm{a}}$ & $8.35^{\mathrm{c}}$ & $7.31^{\mathrm{c}}$ & $10.86^{\mathrm{b}}$ & 0.42 \\
Ether Extract & $13.77^{\mathrm{a}}$ & $13.77^{\mathrm{a}}$ & $4.73^{\mathrm{c}}$ & $5.55^{\mathrm{c}}$ & $8.41^{\mathrm{b}}$ & 0.23 \\
Ash & $6.00^{\mathrm{a}}$ & $5.90^{\mathrm{a}}$ & $2.73^{\mathrm{c}}$ & $3.03^{\mathrm{b}}$ & $3.78^{\mathrm{b}}$ & 0.20 \\
$\mathrm{NFE}^{\mathrm{d}}$ & $42.62^{\mathrm{c}}$ & $42.52^{\mathrm{c}}$ & $58.74^{\mathrm{b}}$ & $61.18^{\mathrm{a}}$ & $55.25^{\mathrm{b}}$ & 1.06 \\
$\mathrm{NDF}^{\mathrm{e}}$ & $61.45^{\mathrm{a}}$ & $60.45^{\mathrm{a}}$ & $43.91^{\mathrm{c}}$ & $50.74^{\mathrm{b}}$ & $34.28^{\mathrm{c}}$ & 0.20 \\
$\mathrm{ADF}^{\mathrm{f}}$ & $31.48^{\mathrm{a}}$ & $31.45^{\mathrm{a}}$ & $17.82^{\mathrm{c}}$ & $24.38^{\mathrm{b}}$ & $15.38^{\mathrm{c}}$ & 0.23 \\
$\mathrm{Calcium}$ & $0.018^{\mathrm{a}}$ & $0.018^{\mathrm{a}}$ & $0.014^{\mathrm{c}}$ & $0.017^{\mathrm{b}}$ & $0.014^{\mathrm{c}}$ & 0.001 \\
\hline
\end{tabular}

${ }^{a b c}$ Mean on same row with different superscripts are significantly different $(\mathrm{P}<0.05),{ }^{\mathrm{d}}$

Nitrogen free extract, ${ }^{\mathrm{e}}$ Acid detergent fibre, ${ }^{\mathrm{f}}$ Neutral detergent fibre

Table.2: Phytochemical component of differently processed Gmelina arborea leaves

\begin{tabular}{lllllll}
\hline \multirow{2}{*}{$\begin{array}{c}\text { Phytochemical } \\
\text { (g/L) }\end{array}$} & \multicolumn{3}{c}{ Processing Techniques } & SEM \\
\cline { 2 - 5 } & Fresh & Chopped & Sun-dried & Air-dried & Boiled-dried \\
\hline Tannin & $4.40^{\mathrm{a}}$ & $4.30^{\mathrm{a}}$ & $2.44^{\mathrm{b}}$ & $2.37^{\mathrm{b}}$ & $1.64^{\mathrm{c}}$ & 2.31 \\
Alkaloid & $6.74^{\mathrm{a}}$ & $6.64^{\mathrm{a}}$ & $1.32^{\mathrm{b}}$ & $1.05^{\mathrm{b}}$ & $0.01^{\mathrm{c}}$ & 0.35 \\
Saponin & $1.51^{\mathrm{a}}$ & $1.41^{\mathrm{a}}$ & $1.32^{\mathrm{b}}$ & $1.05^{\mathrm{c}}$ & $0.01^{\mathrm{c}}$ & 0.28
\end{tabular}


International Journal of Environment, Agriculture and Biotechnology, 5(3)

May-Jun, 2020 / Available: https://ijeab.com/

$\begin{array}{lllllll}\text { Oxalate } & 17.08^{\mathrm{a}} & 17.07^{\mathrm{a}} & 14.44^{\mathrm{b}} & 15.52^{\mathrm{b}} & 10.61^{\mathrm{c}} & 2.86 \\ \text { Flavonoid } & 9.64^{\mathrm{a}} & 9.64^{\mathrm{a}} & 4.50^{\mathrm{b}} & 3.89^{\mathrm{b}} & 3.11^{\mathrm{c}} & 2.43 \\ \text { Steroid } & 43.47^{\mathrm{a}} & 43.45^{\mathrm{a}} & 40.27^{\mathrm{b}} & 41.47^{\mathrm{b}} & 0.00^{\mathrm{c}} & 18.39\end{array}$

${ }^{\mathrm{abc}}$ Mean on same row with different superscripts are significantly different $(\mathrm{p}<0.05)$

Table.3: Rumen bacteria isolation in WAD sheep fed differently processed Gmelina arborea leaves.

\begin{tabular}{|c|c|}
\hline Treatment & Suspected organism \\
\hline Fresh & $\begin{array}{l}\text { Heavy growth of Staphylococus spp }, \text { Streptococcus spp and } \\
\text { Escherichia spp }\end{array}$ \\
\hline Chopped & $\begin{array}{l}\text { Heavy growth of Staphylococus spp }, \underline{\text { Streptococcus spp and }} \\
\text { Escherichia spp }\end{array}$ \\
\hline Sun-dried & Growth of Staphylococus spp, Esherichia spp and Candida spp \\
\hline Air-dried & Growth of Staphylococcus spp, Salmonella spa nd Escherichia spp \\
\hline Boiled-dried & Scanty growth of Staphylococcus spp \\
\hline
\end{tabular}

Table.4: Micro-biological analysis of rumen fluid for parasite identification

\begin{tabular}{lll}
\hline Sample & Appearance & Observation \\
\hline Fresh & Greenish, Watery Sample & $\begin{array}{l}\text { Pus cell-many ova of Teania solium }(\mathrm{H}) \text { Cyst } \\
\text { of Escherichias pp }(\mathrm{H}) \text { seen }\end{array}$ \\
Chopped & Greenish, Watery Sample & $\begin{array}{l}\text { Pus cell-many ova of Teania solium }(\mathrm{H}) \text { Cyst } \\
\text { of Escherichia spp }(\mathrm{H}) \text { seen }\end{array}$ \\
Sun-dried & Watery Greenish Sample & $\begin{array}{l}\text { Ova of round worm }(\mathrm{Hh}), \mathrm{WBc}-\text { many Cyst } \\
\text { of Escherichia spp seen }\end{array}$ \\
Air-dried & Greenish Watery Sample & $\begin{array}{l}\text { Pus cell - many, mature round worm }(\mathrm{H}), \\
\text { Cyst of Escherichia spp }(\mathrm{Hh}) \text { seen. }\end{array}$ \\
Boiled -dried & Formed, Greenish Sample & $\begin{array}{l}\text { Pus cell-Few, ova of round worm }(\mathrm{H}), \text { Cyst } \\
\text { of Escherichia spp }(\mathrm{H}) \text { seen }\end{array}$ \\
\hline
\end{tabular}

Table.5: Isolate distribution and total bacteria count of WAD sheep fed differently processed Gmelina arborea leaves

\begin{tabular}{llllll}
\hline Organisms & \multicolumn{5}{c}{ Processing Techniques } \\
\cline { 2 - 6 } & Fresh & Chopped & Sun-dried & Air-dried & Boiled-dried \\
\hline Salmonella spp & $0.00^{\mathrm{a}}$ & $0.00^{\mathrm{a}}$ & $0.00^{\mathrm{a}}$ & $8.00^{\mathrm{b}}$ & $0.00^{\mathrm{a}}$ \\
Staphylococcus spp & $62.00^{\mathrm{c}}$ & $61.33^{\mathrm{c}}$ & $20.67^{\mathrm{a}}$ & $47.00^{\mathrm{b}}$ & $21.00^{\mathrm{a}}$ \\
Escherichia spp & $14.00^{\mathrm{c}}$ & $14.00^{\mathrm{c}}$ & $13.67^{\mathrm{c}}$ & $11.00^{\mathrm{b}}$ & $0.00^{\mathrm{a}}$ \\
Streptococcus spp & $18.00^{\mathrm{b}}$ & $18.00^{\mathrm{b}}$ & $0.00^{\mathrm{a}}$ & $0.00^{\mathrm{a}}$ & $0.00^{\mathrm{a}}$ \\
Candida spp & $0.00^{\mathrm{a}}$ & $0.00^{\mathrm{a}}$ & $15.33^{\mathrm{b}}$ & $0.00^{\mathrm{a}}$ & $0.00^{\mathrm{a}}$ \\
Total bacteria count & 94.00 & 93.00 & 48.00 & 65.00 & 21.00 \\
X 10 Cfu/mL & & & & & \\
SEM & 0.86 & 4.92 & 1.45 & 2.34 & 1.64 \\
\hline
\end{tabular}

${ }^{a b c}$ Mean on same row with different superscripts are significantly different $(\mathrm{p}<0.05)$ 